\title{
Hemşirelik Öğrencileri Tarafından Uygulanan Akran Eğitim Programının Üniversite Öğrencilerinin Ruhsal Hastalıklara Yönelik İnançlarına Etkisi
}

\author{
Figen ŞENGÜN İNAN**, Neslihan GÜNÜŞEN***, Sevecen ÇELIK İNCE****, \\ Zekiye ÇETINKAYA DUMAN*****
}

\begin{abstract}
$\ddot{O} \mathbf{z}$
Giriş: Çalışmalar, yetişkin bireylerin yanı sıra gençlerin de ruhsal hastalı̆̆ı olan bireylere yönelik olumsuz tutumlara sahip olduklarını göstermektedir. Ayrıca pek çok ruhsal hastalık gençlik döneminde başlamakta ve damgalama nedeniyle psikiyatrik yardım alma gecikebilmektedir. Bu noktada gençlerin ruhsal hastalıklara yönelik olumsuz inanışlarının olumluya dönüştürülmesi önemlidir. Amaç: Bu araştırmanın amacı hemşirelik öğrencileri tarafından uygulanan akran eğitim programının üniversite öğrencilerinin ruhsal hastalıklara yönelik inançları üzerindeki etkisini incelemektir. Yöntem: Araştırma tek grupta ön-test son-test yarı deneysel tasarımdadır. Araştırmanın örneklemini akran eğitimini uygulayan, hemşirelik üçüncü sınıf eğitici akranların ulaştığı hemşirelik dışı bölümlerde okuyan üniversite öğrencileri (n: 144) oluşturmuştur. Öğrencilere ruhsal hastalıklara yönelik damgalama ile baş etmeyi hedefleyen akran eğitim programı uygulanmıştır. Araştırma verileri sosyo-demografik özellikler veri toplama formu ve Ruhsal Hastalıklara Yönelik İnançlar Ölç̧eği ile akran eğitimi öncesi ve sonrasında toplanmıştır. Bulgular: Akran eğitimi uygulanan öğrencilerin çaresizlik ve kişilerarası ilişkilerde bozulma, tehlikelilik ve utanma alt ölçek puan ortalamalarının akran eğitimi sonrasında anlamlı derece azaldığı belirlenmiştir $(p=.001)$. Sonuç: Hemşirelik öğrencileri tarafından uygulanan akran eğitiminin üniversite öğrencilerinin ruhsal hastalıklara yönelik inançlarında olumlu yönde değişim oluşturduğu belirlenmiştir. Bu sonuç doğrultusunda akran eğitimi ruhsal hastalıklara karşı damgalamayı azaltmada kullanılabilecek bir yöntem olarak düşünülebilir. Akran eğitiminin etkinliğinin kontrol gruplu ve uzunlamasına izlem tasarımlarıyla değerlendirilmesi önerilir.
\end{abstract}

Anahtar Sözcükler: Damgalama, Ruhsal Hastalık, Akran Eğitimi, Hemşirelik Öğrencileri, Üniversite Öğrencileri

\section{Abstract \\ The Effects of Peer Education Program Implemented by Nursing Students on the Beliefs of University Students towards the Mental Illness}

Background: Studies show that young adults as well as adults have negative attitudes towards people with mental illness. In addition, most mental illnesses begin in the youth and psychiatric help may be delayed due to stigmatization. At this point, it is important to turn the negative beliefs of young people towards mental illnesses into positive. Objectives: The aim of this study is to investigate the effects of peer education program by nursing students on the beliefs of university students towards mental illness. Methods: This study was carried out a single group with pre-test-post-test, quasi-experimental design. Study sample consisted of the university students from other departments than nursing (n: 144). Peer educators implemented a peer education program that aim combating stigma towards mental illnesses. During the data collection socio-demographic data collection form and Beliefs toward Mental Illness Scale were used. Data were collected before and after the peer education. Results: The mean scores of post-test for incurability and disturbance in interpersonal relationships, dangerousness, and shame subscales is statistically significantly lower than the mean scores of pre-test $(\mathrm{p}=.001)$. Conclusion: It was found that peer education program implemented by nursing students positive effects on the university students' beliefs towards mental illness. In this regard, peer education may be thought as a method for combating stigma towards the mental illness. It is recommended to investigate the effectiveness of peer education with a control group and longitudinal design.

Key Words: Stigma, Mental Illness, Peer Education, Nursing Students, University Students.

\section{Geliş tarihi: 16.12.2019 Kabul tarihi: 08.06.2020}

$\mathrm{R}$ uhsal hastalığa sahip bireyler, toplumun diğer bireyleri tarafından, olumsuz inançlar ile yargılanarak damgalanmakta ve bu durum gerek hasta bireyi gerekse ailesini olumsuz yönde etkilemektedir (1). Çalışmalar, yetişkin bireylerin yanı sıra gençlerin de ruhsal hastalığı olan bireylere yönelik olumsuz tutumlara sahip olduklarını göstermektedir (2-5). Reavley ve Jorm (2011) Avustralya'da 15-25 yaş aralığındaki gençlerin ruhsal hastalığa yönelik tutumlarını incelemişlerdir. Araştırmanın sonucunda gençler şizofreni, psikoz gibi hastalığı olan bireylerden kaçınmaları gerektiğini düşündüklerini belirtmişlerdir (6). Tıp fakültesi öğrencileri ile yapılan bir çalışmada psikiyatri kliniğine çıkmayan öğrencilerin kliniğe çıkanlara oranla daha olumsuz tutumlara sahip oldukları belirlenmiştir (7). Türkiye'de ise gençlerin ruhsal hastalıklara yönelik tutumlarını inceleyen çalışmaların daha çok hemşirelik ve tıp fakültesi ögrencileri ile yapıldığı görülmektedir. Ünal ve arkadaşları (2010), sağlık, mühendislik, mimarlık bölümlerinde okuyan 516 üniversite öğrencisinin ruhsal hastalıklara yönelik inançlarını değerlendirmek için yaptıkları tanımlayıcı çalışmanın sonucunda; öğrencilerin ruhsal hastalıklara yönelik olumsuz tutumlara sahip olduklarını belirlemişlerdir (5).

Bir diğer boyut olarak, pek çok ruhsal hastalık gençlik döneminde başlamakta ve ruhsal hastalıklara yönelik damgalama nedeniyle psikiyatrik yardım arama gecikmektedir. Bu noktada gençlerin ruhsal hastalıklara yönelik olumsuz inanışlarının olumluya dönüştürülmesi oldukça önemlidir $(3,8)$. Üniversite öğrencileriyle yürütülen bir çalışmanın sonuçları

* Bu çalışma, V. Uluslararası IX. Ulusal Psikiyatri Hemşireliği Kongresi’nde (2018) sözel bildiri olarak sunulmuştur. **ỉletişim kurulacak yazar: Dr. Öğr. Üyesi, Dokuz Eylül Üniversitesi Hemşirelik Fakültesi, Psikiyatri Hemşireliği Anabilim Dalı, 35340 İzmir, tel: 023241247 93, Fax: +90 23241247 98, https://orcid.org/0000-0002-9703-4594 e-mail: figensengun@ gmail.com ***Doç. Dr., Dokuz Eylül Üniversitesi Hemşirelik Fakültesi, Psikiyatri Hemşireliği Anabilim Dalı, 35340 İzmir, tel: +90 2324124781 , Fax: +90 2324124789 , https://orcid.org/0000-0002-1666-291X e-mail: neslihan.partlak@deu.edu.tr, neslihan.gunusen@ gmail.com ****Araş. Gör. Dr., Zonguldak Bülent Ecevit Üniversitesi, Sağlık Bilimleri Fakültesi, Psikiyatri Hemşireliği Anabilim Dalı, 67600 Zonguldak, tel: +90 37226133 65, Fax: 037226133 99, https://orcid.org/0000-0003-3113-4565 e-mail: sevecencelik@ hotmail.com, sevecencelik@ beun.edu.tr *****Prof. Dr., Dokuz Eylül Üniversitesi, Hemşirelik Fakültesi, Psikiyatri Hemşireliği Anabilim Dalı, 35340 İzmir, tel: +90 2324124784 , Fax: +90 232 41247 98, https://orcid.org/0000-0002-7447-874X e-mail: zekiyecetinkaya69@gmail.com 
(n: 735) kişisel olarak önyargı ve damgalayıcı tutumlara sahip olmanın psikolojik yardım arama isteğinde azalma ile sonuçlandığını göstermektedir (9). Bir başka çalışmada öğrencilerin hem toplumsal damgalama hem de içselleştirilmiş damgalama algılarının psikolojik yardım arama niyetleriyle negatif bir ilişkiye sahip olduğu belirlenmiştir (8). Gerek toplumsal damgalamanın hasta ve ailesi üzerindeki etkileri, gerekse yardım aramada gecikme gibi nedenlerden dolayı gençlerde ruhsal hastalıklara yönelik olumsuz inançların değiştirilmesi önem kazanmaktadır. Ayrıca üniversite öğrencileri gelecekte toplumsal damgalamayı azaltmada söz sahibi olacak bir pozisyonda bulunabileceklerinden damgalama ile mücadelede öncelikli gruplar arasındadırlar (10). Üniversite öğrencilerinde ruhsal hastalıklara yönelik damgalamayı azaltmada, etkileşim sağlama, ruhsal hastalığa sahip bireylerin öykülerini içeren videoları kullanma ve teorik bilgi verme girişimlerinin uygulandığı sosyal etkileşim ya da video temelli etkileşimin olumsuz tutumları değiştirme ve sosyal mesafeyi azaltmada etkili olduğu belirtilmektedir (10). Ancak literatürde üniversite öğrencilerinde ruhsal hastalıklara yönelik damgalama ile mücadelede akran eğitiminin etkisinin incelendiği bir çalışma sonucuna ulaşılamamıştır.

Akran eğitimi benzer sosyal gruptaki gençlerin belirli bir konuyla ilgili olarak sahip oldukları bilgi, tutum, inanış ve becerilerinin istekli, gönüllü ve eğitimli akranlar tarafından eğitim aktiviteleri aracılığıly değiştirilmesinin hedeflendiği aktif bir süreçtir (11). Akran eğitimi akranların eşit pozisyonda bulunması, benzer gelişim dönemi içinde olmaları nedeniyle benzer dil kullanıyor olmaları ve süreçte herhangi bir değerlendirmenin olmaması nedeniyle uygun bir öğrenme ortamının oluşmasını desteklemektedir (12). Bir başka tanıma göre akran eğitiminin diğer unsurları profesyonel olarak öğretmen olmayan gönüllü bireylerin birbirlerinin öğrenmelerine yardımcı olmaları ve bu süreçte eğitici akranlarında öğrenmeleridir (13). Türkiye'de üniversite öğrencilerinde akran eğitiminin etkinliğinin incelendiği çalışmalar sınırlıdır. Madde bağımlılı̆̆ını önlemede akran eğitiminin uygulandığı bir çalışmada, akran eğitimi alan üniversite öğrencilerinin bağımlılık bilgi ve öz-yeterlik algısı düzeyinin anlamlı derecede arttığı belirlenmiştir (14). Türkiye'de üniversite öğrencileri ve adölesanlara yönelik yürütülen iki çalışmada akran eğitiminin cinsel sağlık ve üreme sağlı̆̆ alanlarında pozitif bir etki oluşturduğu belirlenmiştir (15,16). Bu çalışmanın amacı ise hemşirelik öğrencileri tarafından uygulanan akran eğitim programının üniversitelerin farklı bölümlerinde okuyan öğrencilerin ruhsal hastalıklara yönelik inançları üzerindeki etkisini incelemektir. Hemşireler ruhsal hastalığa sahip birey ve ailesine yönelik toplumdaki olumsuz tutumların değiştirilmesinde topluma liderlik yapan meslek gruplarından biridir (17). Ayrıca hemşirelik öğrencilerinin kariyerlerinin erken dönemlerinde dezavantajlı gruplar için savunuculuk yapma yolunda farkındalık kazanmaları ve desteklenmeleri önemlidir. Bu çalışmanın sonuçlarının üniversite öğrencilerinin ruhsal hastalıklara yönelik olumlu tutum geliştirmelerini destekleyecek müdahalelerin oluşturulmasına katkı vermesi beklenmektedir.

$\mathrm{Bu}$ araştırma hemşirelik öğrencileri tarafindan uygulanan akran eğitim programının üniversite öğrencilerinin ruhsal hastalıklara yönelik tutumları üzerindeki etkisini incelemek amacıyla yapılmıştır.

\section{Araştırma hipotezleri}

$\mathbf{H}_{1}$ : Öğrencilerin ruhsal hastalıklara yönelik inançlar ölçeği çaresizlik ve kişilerarası ilişkilerde bozulma alt boyut puan ortalamalarında akran eğitimi öncesi ve sonrasında anlamlı fark vardır.

$\mathbf{H}_{2}$ : Öğrencilerin ruhsal hastalıklara yönelik inançlar ölçeği tehlikelilik alt boyut puan ortalamasında akran eğitimi öncesi ve sonrasinda anlamlı fark vardır.

$\mathbf{H}_{3}$ : Öğrencilerin ruhsal hastalıklara yönelik inançlar ölçeği utanma alt boyut puan ortalamasında akran eğitimi öncesi ve sonrasinda anlamlı fark vardır.

\section{Araştırmanın Tipi}

Araştırma tek grupta ön test- son test yarı deneysel tasarımdadır.

\section{Araştırmanın Yeri ve Zamanı}

Araştırma Ekim - Aralık 2017 tarihleri arasında İzmir İl’inde bulunan bir üniversitenin farklı bölümlerinde okuyan gönüllü üniversite öğrencileriyle yürütülmüştür.

\section{Araştırmanın Evreni ve Örneklemi}

Araştırmanın örneklemini akran eğitimini uygulayan, hemşirelik üçüncü sınıf eğitici akranların ulaştığı üniversite öğrencileri oluşturmuştur. Örnekleme alma ölçütleri: üniversitenin hemşirelik ve tıp fakültesi dışındaki bölümlerinde okuyor olma, çalışmaya katılımda gönüllü olma ve daha önce ruhsal hastalıklara yönelik damgalama ile mücadele etme amacını taşıyan herhangi bir programda yer almamış olmadır. Akran eğitim programı 144 üniversite öğrencisine uygulanmıştır. Araştırma tamamlandıktan sonra yapılan güç analizinde orta etki boyutu ve 95 güven aralığında çalışmanın gücü . 94 olarak belirlenmiştir.

\section{Araştırmanın Dĕ̆gşkenleri}

Araştırmanın bağımsız değişkeni akran eğitim programıdır. Bağımlı değişkenler, Ruhsal Hastalıklara Yönelik İnançlar Ölçeği'nin alt ölçek puan ortalamalarıdır.

\section{Veri Toplama Araçlart}

Araştırma verileri Sosyo-Demografik Özellikler Veri Toplama Formu ve Ruhsal Hastalıklara Yönelik İnançlar Ölçeği (RHYIÖ) kullanılarak toplanmıştır.

Sosyo-demografik özellikler veri formu; öğrencilerin yaş, cinsiyet, sınıf, en uzun yaşanılan yer, ailede psikiyatrik öykü varlığı, çevrede psikiyatrik öykü varlığı, daha önce psikiyatrik destek alma durumunu içeren toplam yedi sorudan oluşmaktadır.

Ruhsal Hastalıklara Yönelik İnançlar Ölçeği (RHYIÖ); Ölçek, Hirai ve Clum (2000) tarafindan, farklı kültürel gruplardaki bireylerin ruhsal hastalıklar ve tedavisine yönelik inançlarını belirlemek amacıyla geliştirilmiştir. Ölçeğin Türkçe geçerlik güvenirlik çalışması Bilge ve Çam (2008) tarafından yapılmıştır. Ölçek çaresizlik ve kişilerarası ilişkilerde bozulma, 
tehlikelilik ve utanma olmak üzere üç alt ölçekten oluşmaktadır. RHYİÖ, 21 maddeden oluşan 6’lı likert tipi bir ölçek olup tamamen katılmıyorum: 0, çoğunlukla katılmıyorum: 1, kısmen katılmıyorum: 2, kısmen katılıyorum: 3, çoğunlukla katılıyorum: 4, tamamen katılıyorum: 5 şeklinde puanlanmaktadır. Ölçeğin çaresizlik ve kişilerarası ilişkilerde bozulma alt boyutunu: $8,9,10,11,14,16,17,18,19,20,21$. maddeler, tehlikelilik alt boyutunu: 1, 2, 3, 4, 5, 6, 7, 13. maddeler, u tanma alt boyutunu: 12 ve 15. maddeler oluşturmaktadır. Ölçekten elde edilecek en yüksek toplam puan "105”, en düşük puan " 0 ” dır. Ölçek hem toplam puan, hem de alt ölçek puanları üzerinden yorumlanmakta olup, alt ölçeklerdeki yüksek puan olumsuz inancı göstermektedir. Ölçeğin Türk toplumuna uyarlanması çalışmasında cronbach alpha korelasyon katsayısı 0.82 bulunmuştur (18). Bu çalışmada cronbach alpha katsayısı 0.91'dir.

Verilerin Toplanması: Akran eğitimi öncesinde öğrencilere araştırmanın amacı, yöntemi ve sonuçlarının nasıl kullanılacağı açıklanmıştır. Ayrıca öğrencilere araştırmaya katılımın gönüllü olduğu ve istedikleri zaman araştırmadan çekilebilecekleri bilgisi verilmiştir. Araştırma verileri akran eğitimi öncesi ve eğitim uygulandıktan sonra toplanmıştır.

\section{Yapılan İslem/Müdahale:}

\section{Eğitici akranların eğitimi}

Akran eğitiminin etkinliğini belirleyen temel unsurlardan biri eğitici akranların istekli ve deneyimli öğrenciler arasından seçilmesidir (13). Bu noktada psikiyatri hemşireliği teori ve uygulamasını tamamlamış üçüncü sınıf hemşirelik öğrencileri çalışmanın amacı konusunda bilgilendirildikten sonra, gönüllülük esasına dayalı olarak eğitici akran olmak üzere araştırmaya davet edilmişlerdir. Psikiyatri hemşireliği teori ve uygulamasını tamamlamış 40 öğrenci gönüllü olmuştur. Gönüllü öğrencilere ruhsal hastalıklara yönelik kendi temel inançlarını ve ulaşacakların grubun inançlarını olumlu yönde değiştirmelerini hedefleyen altı oturumdan oluşan bir eğitim programı uygulanmıştır. Bu program Üstün ve İnan tarafından 2012-2013 eğitimöğretim yılında geliştirilmiş ve daha sonra programın içeriği ve sonuçları yayımlanmıştır (19). Bu araştırma kapsamında ise mevcut program akran eğitimine yönelik oturumlar eklenerek güncellenmiştir. Eğitici akranlar, damgalama nedenleri ve etkileri, temel olumsuz inançlar ve gerçekler ve gençlerde damgalama konularında makale tartışma oturumlarında yer almışlardır. Oturumların içeriğinde şizofreni hasta ve ailelerinin yaşamlarından kesitleri ve damgalanmanın etkilerini içeren bir belgesel ve uzman sunumları yer almış ve bir yöntem olarak kavram haritası çalışmalarından yararlanılmıştır. Eğitici akranlar tüm bu aşamalarda aktif olarak yer almıştır. Ayrıca eğitici akranlar Şizofreni Dayanışma Derneği’ne hasta ve ailelerinin damgalanma deneyimlerini anlamak için gözlem amaçlı olarak bir kez gitmişlerdir. Eğitici akranlar tarafindan uygulanacak akran eğitiminin içeriğinin yapılandırılmasına yönelik iki oturum yer almıştır. Bu oturumlarda eğitici akranların, akran eğitiminde kullanmak üzere standart bir sunum ve broşür oluşturmaları sağlanmıştır. Broşür ve sunumun ana başlıkları, süreçte kullanılacak yöntemler araştırmacılar tarafından standardize edilmiş ve sunumun ve broşürün son halinin verilmesinde öğretim elemanı tarafından öğrencilere danışmanlık sağlanmıştır. Ayrıca eğitici akranlarla kendi eğitim süreçlerinde de yer alan hastaların ve ailelerinin hastalıkla mücadele ve damgalanma deneyimlerini içeren belgeseli akran eğitim sürecinde nasıl kullanacakları ve tartışma soruları çalışılmıştır. Hasta ve ailelerinin damgalanma deneyimlerini içeren bu belgesel toplumda farkındalık geliştirme amacıyla eğitsel ve farkındalık müdahalelerinde kullanılmak üzere geliştirilmiş ve alanda çalışan uzmanların kullanımına açık bir belgeseldir.

Akran eğitim programı ve uygulama süreci

Akran eğitim programı bir ya da iki eğitici akran önderliğinde 8-10 kişiden oluşan gönüllü üniversite öğrencilerine uygulanmıştır. Eğitici akranlar kendi seçtikleri uygun yer ve ortamlarda gönüllü öğrencilere ulaşmıştır. Eğitici akranlar akran eğitim programını kaldıkları yurt, ev ya da uygun olan sınıf ortamlarında uygulamışlardır. Eğitim oturumu yaklaşık olarak 6090 dakika sürmüştür. Akran eğitim programının ana başlıkları: Damgalama kavramı ve etkileri, ruhsal hastalıklara yönelik yanlış inançlar ve gerçekler başlıklarını içeren bir sunum, hasta ve ailesinin yaşamından kesitleri içeren belgesel gösterimi ve grup tartışmalarını içermiştir (Tablo 1). Eğitici akranlar öğrencilere damgalama nedir, neden damgalıyoruz, ruhsal hastalığa sahip bireylere yönelik düşünceleriniz nedir, yaklaşımınız nasıl, damgalama nedeniyle hasta ve aileleri neler yaşayabilir gibi sorular yöneltmiş ve tüm bu soruların cevaplarına ilişkin katılımcılara bilgi sağlamışlardır. Ayrıca program sonrasında eğitici akranlar, geliştirdikleri broşürü katılımcılara vermişlerdir. Eğitici akranların bu süreci nasıl algıladıkları ve deneyimlerini paylaşmaları için akran eğitimi verilirken çektikleri fotoğrafları ve deneyimlerini eğitim sonrasında araştırmacılar ve kendi grup arkadaşları ile paylaşmaları sağlanmıştır.

Tablo 1. Akran Eğitim Programı

\begin{tabular}{ll}
\hline İçerik & Yöntem \\
\hline Damgalama Kavramı & Sunum \\
Toplumsal damgalamanın hasta ve ailesi üzerindekması & \\
\hline Mitler ve Gerçekler & Belgesel gösterimi \\
\hline Şizofreni hastası ve ailesi olmak & Grup Tartışması \\
\hline
\end{tabular}

\section{Verilerin Değerlendirilmesi}

Çalışmanın verileri, SPSS 22.0 paket programı aracılığıyla tanımlayıcı istatistikler için sayı, yüzde, ortalama ve standart sapma ile değerlendirilmiştir. Verilerin dağılımı Shapiro Wilk testi ile incelenmiş ve verilerin normal dağılım göstermediği belirlenmiştir. Öğrencilerin ön test-son test alt ölçek puan ortalamalarının karşılaştırılması Wilcoxon işaret testi ile incelenmiştir.

\section{Araştırmanın Etik Yönü}


Araştırma için kurum izni alındıktan sonra etik kurul onayı alınmıştır (28.09.2017/GOA-3583). Araştırmaya katılan tüm öğrencilerden sözlü ve yazılı onam alınmıştır.

\section{Bulgular}

Akran eğitimi uygulanan öğrencilerin sosyo-demografik özelliklerine ilişkin bulgular Tablo 2'de verilmiştir.

Tablo 2. Akran Eğitimi Alan Üniversite Öğrencilerinin Sosyo-Demografik Özellikleri

\begin{tabular}{|c|c|c|}
\hline Sosyo-demografik Özellikler & \multicolumn{2}{|c|}{$\overline{\mathbf{X}} \pm \mathbf{S S}$} \\
\hline \multirow[t]{2}{*}{ Yaş } & \multicolumn{2}{|c|}{$\begin{array}{c}20.18 \pm 01.62 \\
(\min : 17-\max : 28)\end{array}$} \\
\hline & $\mathbf{n}$ & $\%$ \\
\hline \multicolumn{3}{|l|}{ Cinsiyet } \\
\hline Kadın & 89 & 61.8 \\
\hline Erkek & 55 & 38.2 \\
\hline \multicolumn{3}{|l|}{ Sinıf } \\
\hline 1.sinif & 44 & 30.6 \\
\hline 2.sinif & 68 & 47.2 \\
\hline 3.sinif & 30 & 20.8 \\
\hline 4.sinif & 2 & 1.4 \\
\hline \multicolumn{3}{|l|}{ En uzun yaşanılan yer } \\
\hline Köy ve ilçe & 60 & 41.7 \\
\hline İl & 84 & 58.3 \\
\hline \multicolumn{3}{|c|}{ Çevrede psikiyatrik öykü varlığı } \\
\hline Var & 53 & 36.8 \\
\hline Yok & 91 & 63.2 \\
\hline \multicolumn{3}{|c|}{ Daha önce ruhsal destek alma durumu } \\
\hline Evet & 28 & 19.4 \\
\hline Hayır & 116 & 80.6 \\
\hline Toplam & 144 & 100.0 \\
\hline
\end{tabular}

Öğrencilerin (n: 144) yaş ortalaması $20.18 \pm 01.62, \% 61.8$ ’i (n: 89) kadın, \%47.2’si ikinci sınıftır. Öğrencilerin \%58.3'ünün en uzun yaşadıkları yer il olup, \%63.2'sinin çevresinde ruhsal bir hastalık tanısına sahip bir birey yoktur. Öğrencilerin \%80.6'sı daha önce herhangi bir ruhsal destek almadığını belirtmiştir (Tablo 2).

Tablo 3. Öğrencilerin Ruhsal Hastalıklara Yönelik İnançlar Ölçeği Alt Ölçek Puan Ortalamalarının Karşılaştırılması (n: 144)

\begin{tabular}{lccrr} 
& Ön-test & Son-test & \\
RHİÖ alt boyutları & $\overline{\mathbf{X}} \pm \mathbf{S S}$ & $\overline{\mathbf{X}} \pm \mathbf{S S}$ & $\mathbf{z}^{*}$ & $\mathbf{P}$ \\
\hline Çaresizlik ve kişiler arası ilişkilerde bozulma & & & & \\
\hline Tehlikelilik & $24.36 \pm 11.28$ & $17.95 \pm 10.22$ & -6.887 & $\mathbf{. 0 0 1}$ \\
\hline Utanma & $20.45 \pm 7.60$ & $13.10 \pm 7.25$ & -8.994 & $\mathbf{. 0 0 1}$ \\
\hline
\end{tabular}

*Wilcoxon Signed test

Öğrencilerin Ruhsal Hastalıklara Yönelik İnançlar Ölçeği alt ölçek ön-test ve son-test puan ortalamaları arasındaki fark Wilcoxon işaret testi ile değerlendirilmiştir. Öğrencilerin çaresizlik ve kişilerarası ilişkilerde bozulma, tehlikelilik ve utanma alt ölçek puan ortalamalarının akran eğitimi sonrasında anlamlı derece azaldığı belirlenmiştir $(\mathrm{p}=.001)($ Tablo 3$)$.

\section{Tartışma}

$\mathrm{Bu}$ çalışmada toplumsal damgalama ve ayrımcılıkla mücadele etmeyi hedefleyen akran eğitim programının gençlerin ruhsal hastalıklara yönelik olumsuz inançları üzerindeki etkinliği incelenmiştir. Çalışma benzer programların yapılandırılmasına yönelik önemli veriler sunmaktadır. Ayrıca bu çalışma hemşirelik öğrencileri önderliğinde uygulanan bir akran eğitiminin gençlerin ruhsal hastalıklara yönelik inançları üzerindeki etkisinin incelendiği ilk çalışmadır.

Çalışmanın sonuçları akran eğitimi sonrası üniversite öğrencilerinin ruhsal hastalığa sahip bireylerin tehlikeli oldukları yönündeki inanışları, iyileşmeye vurgu yapan çaresizlik ve kişilerarası ilişkilerde bozulma inanışları ve utanma inanışlarında pozitif yönde bir değişim olduğunu göstermektedir. Hipotez 1, 2 ve 3 doğrulanmıştır. Literatürde farklı alanlarda uygulanan akran eğitim programlarının olumlu etkilerine vurgu yapılmaktadır $(14,15,16)$. Ancak akran eğitiminin ruhsal hastalığa sahip bireylere yönelik her bir alt inanç üzerindeki etkisini inceleyen çalışma sonucuna ulaşılamamıştır. Bu nedenle bu bulgunun tartışılması damgalamaya odaklanan çalışmanın sonuçları doğrultusunda ele alınmıştır. Toplumsal damgalama ile baş etmeye yönelik temel yaklaşımlardan biri eğitimdir. Eğitim müdahalelerinde toplumda var olan ruhsal hastalıklara yönelik 
yaygın olumsuz inanışların gerçek bilgi ile değiştirilmesi yoluyla tutum değişikliği sağlamak hedeflenmektedir. İkinci temel yaklaşım ise ruhsal hastalığa sahip kişilerle toplumun üyelerini bir araya getirme ve bu etkileşim yoluyla olumlu tutum değişimi sağlamayı hedefleyen kişilerarası etkileşim yaklaşımıdır $(20,21)$. Özellikle eğitim ve etkileşimin birlikte yer aldığ programların toplumsal damgalama ile mücadelede önemine vurgu yapılmaktadır (21). Bu çalışmada akran eğitim programı içeriğinde katılımcılara hem eğitim hem de video temelli etkileşim firsatı sunulmuştur. Özellikle ruhsal hastalıklarda iyileşmenin mümkün olduğu ve hastalığa değil kişiye odaklanmak gerektiği mesajlarını veren yaklaşımların etkin olduğundan söz edilmektedir (22). Akran eğitimi içerisinde yer alan belgeselde hastaların bireysel boyutta hastalıktan ve toplumsal damgalanmadan nasıl etkilenildiğine vurgu yapılmakta ve hastalıktan çok hastaya odaklanılmaktadır. Ayrıca belgeselde uzmanlar tarafından şizofreniye özgü bilgi sağlanmakta ve tehlikelilik gibi olumsuz kalıp yargılara ilişkin açıklamalar yer almaktadır. Belgesel-video gibi materyaller kullanılarak yapılan çalışmaların da inançlar üzerindeki olumlu etkisi vurgulanmaktadır $(23,24)$. Benzer şekilde müdahalelerde damgalayıcı tutumların altında yatan gizli inançları fark ettirme ve iyileşmeye vurgu önerilmektedir (25). Bu çalışmada akran eğitiminin içeriğinin hastaların içinde bulundukları durumun tıbbi bir hastalık olduğu, tedavi seçeneklerinin bulunduğu, iyileşmede aile ve toplum desteğinin önemli olduğu mesajının eğitici akranlar aracılığıyla verilmesi olumlu tutumların gelişmesini desteklemiş olabilir.

Akran eğitim programlarının etkinliğini belirleyen önemli noktalardan biri motive ve gönüllü eğitici akranlarla çalışılmasıdır. Akran eğitiminde eğiticinin kendi gelişim grubundan ve benzer özelliklerde olması eğitimi alan kişilerde sempati, anlaşılıyor olma duygusu gibi olumlu duygularla bu eğitim türünün etkinliğini arttırmaktadır (12). Akran eğitim süreci içinde işbirliğinin sağlanması ve otorite ya da değerlendirmeye yönelik bir tutumun olmaması, ayrıca eğitici akranların programın geliştirilmesi, uygulanması ve değerlendirilmesi gibi tüm süreçlere dahil olmasının (11), materyal geliştirme sürecinde bağımsız çalışmalarının desteklenmesinin akran eğitiminin etkinliğini arttıran diğer faktörler olduğu söylenebilir.

\section{Sonuçların Uygulamada Kullanımı}

Hemşirenin toplumsal sorunlara duyarlı olması ve dezavantajlı gruplara yönelik savunucu rolünü göz önüne aldığımızda hemşirelik öğrencileri ile yürütülen bu çalışma öğrenciler için eşsiz bir deneyim özelliği taşımaktadır. Bu çalışmanın sonuçları akran eğitiminin üniversite öğrencilerinin ruhsal hastalıklara yönelik inanışları üzerinde olumlu bir etki oluşturduğunu göstermektedir. $\mathrm{Bu}$ sonuç ruhsal hastalıklara yönelik damgalama ile mücadelede akran eğitim programlarının üniversite öğrencilerine yönelik girişimsel çalışmaların bir parçası olabileceğini göstermektedir. Ek olarak akran eğitiminin etkinliğinin kontrol grubu ve uzunlamasına izlem içeren tasarımlarla test edilmesi önerilir. Ayrıca, gelecekte üniversite öğrencilerine yönelik yürütülecek akran eğitimi çalışmalarında hemşirelik öğrencilerinin yer alması ve akran eğitimcisi olmanın hemşirelik ögrencilerini nasıl etkilediğini açıklamaya yönelik çalışmaların yapılması önerilir.

\section{Kisıtlılıklar}

$\mathrm{Bu}$ çalışmanın Türkiye'nin batısındaki bir üniversitenin gönüllü öğrencileriyle yürütülmüş olması ve çalışmada kontrol grubunun yer almaması ayrıca değişimin kalıcılığını değerlendirmek adına izlem ölçümlerinin yapılmamış olması çalışmanın sinırlılıklarıdır.

\section{Bilgilendirme}

Yazar katkıları: fikir F.Ş.İ; tasarım F.Ş.İ, N.G., Z.Ç.; verilerin toplanması ve analizi F.Ş.İ, N.G., S.Ç.İ.; literatür tarama ve makale yazımı F.Ş.I.', S.Ç.İ; eleştirel değerlendirme Z.Ç.D., N.G. tarafından yapılmıştır. Araştırma için 28.09.2017 tarih ve GOA-3583 karar numarası ile etik kurul onayı alınmıştır. Yazarlar arasında herhangi bir çıkar çatışması bulunmamaktadır. Çalışmada yer alan tüm öğrencilere teşekkür ederiz.

\section{Kaynaklar}

1. Günay S, Bekitkol T, Beycan Ekitli G, Yıldırım S. The determining of a faculty of nursing students' beliefs toward mental disorders. J Psychiatr Nurs 2016;7(3):129-134. https://doi.org/10.5505/phd.2016.43534

2. Akdede BK, Alptekin K, Topkaya ŞÖ, Belkiz B, Nazlı E, Özsin E, ve ark. Gençlerde şizofreniyi damgalama düzeyi. Yeni Symposium 2004;42(3):113-117.

3. Oban G, Küçük L. Damgalama erken yaşlarda başlar... Gençlerde ruhsal hastalıklara yönelik damgalamayla mücadelede eğitimin rolü. Psikiyatri Hemşireliği Dergisi 2011;2(3):141-148.

4. Öztürk A, Kaçan Softa H, Ulaş Karaahmetoğlu G. Kastamonu üniversitesinde öğrenim gören hemşirelik öğrencilerinin ruhsal hastalıklara karşı inançları ve psikiyatri hemşireliği dersinin etkisi. Uluslararası Hakemli Psikiyatri ve Psikoloji Araştırmaları Dergisi 2015;(4):146-146. https://doi.org/10.17360/uhppd.2015414027

5. Ünal S, Hisar F, Çelik B, Özgüven Z. Üniversite öğrencilerinin ruhsal hastalığa yönelik inançları. Düşünen Adam Psikiyatri ve Nörolojik Bilimler Dergisi 2010;23(3):145-150.

6. Reavley NJ, McCann TV, Jorm AF. Mental health literacy in higher education students. Early Interv Psychiatry 2012;6 (1):45-52. https://doi.org/10.1111/j.1751-7893.2011.00314.x

7. Ighodaro A, Stefanovics E, Makanjuola V, Rosenheck R. An assessment of attitudes towards people with mental illness among medical students and physicians in Ibadan, Nigeria. Acad Psychiatry 2015;39(3):280-285. https://doi.org/10.1007/s40596-014-0169-9

8. Pheko MM, Chilisa R, Balogun SK, Kgathi C. Predicting intentions to seek psychological help among Botswana university students: The role of stigma and help-seeking attitudes. Sage Open 2013;3:1-11. https://doi.org/10.1177/2158244013494655 
9. Lally J, ó Conghaile A, Quigley S, Bainbridge E, McDonald C. Stigma of mental illness and help-seeking intention in university students. The Psychiatrist 2013;37(8):253-260. https://doi.org/10.1192/pb.bp.112.041483

10. Yamaguchi S, Wu SI, Biswas M, Yate M, Aoki Y, Barley EA, et al. Effects of short-term interventions to reduce mental health-related stigma in university or college students: a systematic review. J Nerv Ment Dis 2013;201(6):490-503.

11. United Nations Population Fund (UNPF) and Youth Peer Education Network (Y-PEER). Training of trainers manual. $\begin{array}{lllll}\text { Youth peer toolkit. } & 2004 . & \text { Retrieved from: }\end{array}$ https://www.unfpa.org/sites/default/files/jahiapublications/documents/publications/2006/ypeer tot.pdf. Erişim Tarihi: 11.09.2017.

12. Family Health International. Evidence-based guidelines for youth peer education, Family Health International, Triangle Park, NC. 2010. https://www.fhi360.org/sites/default/files/media/documents/EvidenceBased\%20Guidelines\%20for\%20Youth\%20Peer\%2 0Education\%20Brief.pdf. Erişim Tarihi: 04.09.2017.

13. Topping KJ. The effectiveness of peer tutoring in further and higher education: A tipology and review of the literature. Higher Education 1996;32(3):321-345.

14. Akkuş D, Eker F, Karaca A, Kapısız Ö, Açıkgöz F. Is peer education program an effective model in prevention of substance addiction in high-school teens? Journal of Psychiatric Nursing 2016;7(1):34-44.

15. Bulduk S, Erdogan S. The effects of peer education on reduction of the HIV/ sexually transmitted infection risk behaviors among Turkish university students. J Assoc Nurses AIDS Care 2012; 23(3):233-243. http://dx.doi.org/10.1016/j.jana.2011.02.003.

16. Polat S, Atıcı A, Karakaş D, Çulha GG, Erdoğan S. Peer training increases the level of knowledge on sexual and reproductive health in adolescents. J Trop Pediatr 2012;58(2):96-101. http://dx.doi.org/10.1093/tropej/fmr041.

17. Açıkgöz F, Akkuş D. Ruhsal hastalıklarda damgalama ile mücadele: Anahtar rol üstlenen meslekler. Düzce Üniversitesi Sağlık Bilimleri Enstitüsü Dergisi 2018;8(3):142-146.

18. Bilge A, Çam O. Reliability and validity belief towards mental health illness. Anadolu Psikiyatri Dergisi 2008;9(2): 9196.

19. Üstün B, İnan FŞ. Psikiyatri hemşireliği uygulamasına bir örnek: Damgalamayla mücadele eğitim programı. Hemşirelikte Eğitim ve Araştırma Dergisi 2018;15(2):131-135. https://doi.org/10.5222/HEAD.2018.131

20. Corrigan PW, Morris SB, Michaels PJ, Rafacz JD, Rüsch N. Challenging the public stigma of mental illness: A metaanalysis of outcome studies. Psychiatr Serv 2012;63(10):963-973. https://doi:10.1176/appi.ps.201100529

21. Michaels PJ, López M, Rüsch N, Corrigan PW. Constructs and concepts comprising the stigma of mental illness. Psychology, Society, \& Education 2012;4(2):183-194.

22. Clement S, Jarrett M, Henderson C, Thornicroft G. Messages to use in population-level campaigns to reduce mental health-related stigma: Consensus development study. Epidemiol Psychiatr Sci 2010;19(1):72-79. https://doi.org/10.1017/S1121189X00001627

23. Larøi F, Van der Linden M. The effects of a documentary film on reducing stigmatisation about schizophrenia. Psychosis 2009;1(1):61-72. https://doi.org/10.1080/17522430802578395

24. Thonon B, Pletinx A, Grandjean A, Billieux J, Larøi F. The effects of a documentary film about schizophrenia on cognitive, affective and behavioural aspects of stigmatisation. J Behav Ther Exp Psychiatry 2016;50:196-200. https://doi.org/10.1016/j.jbtep.2015.08.001

25. Knaak S, Mantler E, Szeto A. Mental illness-related stigma in healthcare: Barriers to access and care and evidence-based solutions. Healthc Manage Forum 2017;3(2):111-116. https://doi.org/10.1177/0840470416679413 